Jan Kluza

ORCID: 0000-0002-0929-6093

Jagiellonian University

Konrad Sączek

ORCID: 0000-0002-5094-8161

Jagiellonian University

DOI: $10.19195 / 1733-5779.29 .13$

\title{
The Internet as a public place and a place of committing a prohibited act: Comments regarding the judgment of the Supreme Court of the Republic of Poland, case ref. no. IV KK 296/17
}

\section{JEL Classification: K14}

Keywords: Internet, public place, public act

Słowa kluczowe: Internet, miejsce publiczne, działanie publiczne

Abstract: The paper concerns the analysis of the possibility for classifying the Internet as a public place, which is of extraordinary legal significance with regard to the fulfilment of the criteria of many prohibited acts. Such a statement was presented by the Supreme Court of the Republic of Poland in its judgment of 17 April 2018, case ref. no. IV KK 296/17. This paper attempts to assess the standpoint of the Supreme Court of the Republic of Poland and the way it is reflected in various factual situations. To determine whether the Internet can constitute a public space in the sense of criminal law, several factors must be indicated, including, first of all, the application of an appropriate interpretation of the norms of criminal law. 


\title{
Internet jako miejsce publiczne popełnienia przestępstwa - uwagi na tle wyroku Sądu Najwyższego z dnia 17 kwietnia 2018 roku, sygn. akt IV KK 296/17
}

\begin{abstract}
Abstrakt: Artykuł zawiera analizę możliwości zakwalifikowania Internetu jako miejsca publicznego, co ma swoje doniosłe znaczenie prawne dla spełnienia znamion wielu typów czynów zabronionych. Taką tezę zaprezentował Sąd Najwyższy w wyroku z dnia 17 kwietnia 2018 roku (sygn. IV KK 296/17). Niniejszy tekst to próba oceny stanowiska Sądu Najwyższego oraz jego przełożenia na różnorakie stany faktyczne. W kwestii tego, czy Internet może stanowić miejsce publiczne w rozumieniu prawa karnego, trzeba wskazać na kilka okoliczności, przede wszystkim zastosowanie właściwego sposobu wykładni norm prawa karnego.
\end{abstract}

\section{Introduction}

The analysis presented in this paper aims at defining the Internet as a place of committing a crime, and particularly at perceiving the World Wide Web as a public place within which the features of many types of prohibited acts are fulfilled. In the judgment of 17 April 2018, the Supreme Court of the Republic of Poland stated that the Internet may be perceived as a public place where a crime has been committed. The decision of the Supreme Court of the Republic of Poland raises the issue which is particularly significant from the point of view of the modern development of technology. It is, in fact, commonly known that the content of the vast majority of provisions which classify crimes in the criminal code has the wording that was implemented in 1997, at the time when the Internet in Poland was a rarity. In view of the above and with regard to the judgment of the Supreme Court of the Republic of Poland, there is a question if, and possibly what, behaviours exhibited online may constitute the basis for criminal liability. That question concerns not only crimes included in the specific part of the Criminal Code, but also all types of prohibited acts included in the criminal provisions of specific acts which may potentially be committed online. This fact is even more noticeable when it comes to the Code of Petty Offences of 1971 which, compared to the Criminal Code, has been less frequently amended; moreover, it specifies penalties for acts that may potentially be committed in the Internet, and it is very likely that its authors never took such a possibility into consideration.

\section{Factual circumstances and judgment of the Supreme Court of the Republic of Poland}

In 2016, a certain organisation published in the Internet some images involving offensive content. The drawings showed, among other things, two figures in a position suggesting anal sex and the inscription: "Zakaz ped..., homoseksualiści wszystkich krajów, leczcie się" ("No faggotting, homosexuals of all countries, cure 
yourselves"). To punish the perpetrator, the Police submitted a motion for penalty pursuant to Article 141 of the Code of Petty Offences, which states the following: "Any person who places obscene adverts, notes or drawings in a public place or uses obscene language, shall be subject to the penalty of limitation of liberty, a fine up to 1,500 PLN or a reprimand." The District Court adjudicating in that case stated that the above-mentioned action may be considered as obscene, however, the perpetrator did not meet the criteria of a petty offence, because it cannot be said that the behaviour exhibited in the Internet is an action performed in a public place. Pursuant to this interpretation, the court discontinued the legal proceedings.

The Commissioner for Human Rights lodged a cassation complaint against the said judgment, to the disadvantage of the defendant. In the cassation, the Commissioner for Human Rights disputed the judgment of the court of first instance with regard to the interpretation of the phrase "a public place" and indicated that "Contrary to the conviction expressed by the District Court, the Internet is not only a data record stored on computers, but it constitutes a World Wide Web, a system." Consequently, in the petitum of the cassation, the Commissioner for Human Rights requested that the Supreme Court of the Republic of Poland reverse the discontinuation of the proceedings and refer the case back to the court of first instance for re-examination. The Supreme Court of the Republic of Poland upheld the cassation complaint of the Commissioner for Human Rights and acknowledged that the Internet is a public place. Moreover, the Court also indicated that the appealed ruling of the District Court was not justified thoroughly, and the arguments included in it were anachronistic and failed to take the present technology into account. According to the Supreme Court of the Republic of Poland, the content published on the Internet constitutes "a certain space," and, therefore, a website, which may be visited by everyone without any restrictions, is a public place. At the same time, the Supreme Court of the Republic of Poland noted that not every website may be treated as a public space: "The access to some content requires, among other things, logging in, and such situations may raise a doubt whether we deal with a public space." With regard to the above, the Supreme Court of the Republic of Poland revoked the appealed decision concerning the discontinuation of the proceedings and referred the case back to the District Court for re-examination.

In the further part of the paper, we would like to analyse, among other things, the fulfilment of the criteria of a public place through actions performed on popular social media portals (for example, Facebook, Instagram) by taking into account their specificity and privacy settings, i.e. to determine what conditions must be fulfilled in order to consider the activity on social media portals as an act performed in a public place. 


\section{Public place and public action as the criteria of a prohibited act}

The legislator, in numerous descriptions of types of prohibited acts, uses the criterion of a public action or an action in a public place, which indicates that they clearly distinguish between these two forms of a perpetrator's act. The requirement of a public action of a perpetrator constitutes the criterion of such crimes as public insult to the Polish nation or the Republic of Poland (Article 133 of the Criminal Code), public blasphemy against an object of religious worship (Article 196 of the Criminal Code) and public promotion of paedophilia (Article 200b of the Criminal Code). The Criminal Code also specifies acts not performed publicly (Article 213.1 of the Criminal Code). Moreover, a public action is also one of the requirements for admitting the hooligan nature of an offence (Article 57a and 115.21 of the Criminal Code). On the other hand, in Article 261 of the Criminal Code, the legislator uses the criterion of "a public place" with regard to the object of the act of insult, which does not rule out the acting of a perpetrator in a public place. Things are different when it comes to the Code of Petty Offences, which, among criteria of prohibited acts specified in it, applies the notion of the acting of a perpetrator in a public place - for example, demonstrative disregard of the Polish nation, the Republic of Poland or its constitutional bodies in a public place (Article 49.1 of the Code of Petty Offences), causing scandal in a public place (Article 51.1 of the Code of Petty Offences) - as well as the notion of a public action - for example, public incitement to a crime (Article 52a of the Code of Petty Offences), public use of a medal, badge, dress or uniform without being entitled to them (Article 61.1 of the Code of Petty Offences). With regard to the above, it is impossible to admit that these notions should have identical meaning.

Pursuant to the Polish Criminal Code, a public action is defined as "undertaking a behaviour in a place which is accessible to a group of people of unspecified number and sex," whereby, "In a particular case, the behaviour of a perpetrator does not have to be actually noticed by a larger number of people."1 At the same time, it can be noticed in the doctrine that "The term 'publicly' is not the same as the expression 'in a public place." The latter indicates a place available for an unlimited group of entities, even if at the moment of the performance of an act by a perpetrator, they are the only person present there. In jurisdiction and literature, it is assumed that certain behaviour, such as communicating specific content during a whispered conversation at a café or sending a letter to a precisely defined person, are not of public nature." 2 The Court of Appeal in Łódź also provided a just statement which says that

${ }^{1}$ P. Kardas, [in:] W. Wróbel, A. Zoll, Kodeks karny. Część szczególna, vol. 2. Czesść I. Komentarz do art. 117-211a [Criminal Code. Detailed Part, vol. 2. Part I. Comment to Articles 117-211a], comment to Article 133, thesis 25.

2 Ibidem, thesis no. 27. 
Acting in a public place is not the same as acting publicly, because, even if in most cases these concepts jointly characterise a perpetrator's behaviour, the intersection of their meanings cannot be excluded with regard to the unique factual circumstances of an examined case. ${ }^{3}$

Already pursuant to the previously applicable Criminal Code of $1969,{ }^{4}$ the Supreme Court stated that

Acting "publicly" [...] takes place if, with regard to place of action or circumstances and method of a perpetrator's acting, their behaviour is or may be available (visible) to an unspecified number of people, whereby a perpetrator, being aware of such a possibility, at least agrees to it. ${ }^{5}$

The above-mentioned ruling clearly indicates that the prerequisite for public action constitutes a modal component of the objective features of a prohibited act, and, as such, it must be included in the intent of a perpetrator within the scope resulting from the objective features of a particular prohibited act. This causes that in the case of prohibited acts, with regard to which the law requires an action with the direct intent, the willingness of a perpetrator to commit an act must refer to a public action. In the famous case concerning a singer from a heavy metal band accused of insulting religious feelings, the Supreme Court of the Republic of Poland also stated that

the criteria concerning the audience are met, if an action involving an insult is registered and then transmitted to a wider group of people by means of printed press or Internet transmission. The publication of such a content may fulfil the features of the crime under Article 196 of the Criminal Code [cf. W. Wróbel, [in:] W. Wróbel, A. Zoll, op. cit., p. 662]. It must also be agreed that the features of the crime under Article 196 of the Criminal Code are not fulfilled when it comes to an action observed by a person or a group of people who voluntarily agree to have contact with the content that may cause insult of religious feelings. ${ }^{6}$

Therefore, a public action takes place only when this action can be seen by an unspecified number of persons, regardless of the place where this action was performed. Based on this, the numerical description of "an unspecified number of people" is of key significance, because an action, which may be seen by any random witness, is not a public action. ${ }^{7}$ The visibility of such behaviour must be entirely real and not just hypothetical, which results from the protective purpose of

3 Judgment of the Court of Appeal in Łódź of 8 October 2015, II AKa 178/15, LEX no. 1923902; cf.: Judgment of the Supreme Court of the Republic of Poland of 20 July 1933, III K 545/33, LEX no. 389985 .

${ }^{4}$ The act of 19 April 1969 - the Criminal Code, Polish Journal of Laws of 1969, no. 13, item 94.

${ }^{5}$ Resolution of the Supreme Court of the Republic of Poland of 20 September 1973, VI KZP 26/73, LEX no. 18637; cf.: Judgment of the Supreme Court of the Republic of Poland of 26 March 1973, Rw 279/73, LEX no. 18612.

${ }^{6}$ Decision of the Supreme Court of the Republic of Poland of 5 March 2015, III KK 274/14, LEX no. 1734689.

7 J. Kulesza, [in:] M. Królikowski, R. Zawłocki (eds.), Kodeks karny. Część szczególna, vol. 1. Komentarz. Art. 117-221 [Criminal Code. Detailed Part, vol. 1. Comment. Articles 117-221], Warszawa 2017, p. 125. 
particular sanctioned norms, and also from the principle of proportionality referred to under Article 31.2 of the Constitution of the Republic of Poland. ${ }^{8}$ Pursuant to the Criminal Code, a perpetrator's action, which was not performed publicly and which is specified under Article 213 of the Criminal Code, is in opposition to a public action, and this may be helpful with regard to the interpretation of quantity concerning "an unspecified group of people." Pursuant to the said article, a defamatory accusation is not made publicly, if it is addressed to a particular person or a group of individually designated persons, and the size of the group does not matter as long as it is possible to determine its members. ${ }^{9}$

As mentioned above, there is an overlapping relationship between a public action and an action in a public place. The doctrine defines a public place as a generally available place to which everyone has unrestricted access, for instance, a park, a street, a shop, as well as a place where it is necessary to hold a specific entry pass - a ticket, an invitation, for example, a stadium, a cinema or a tram. At the same time it does not matter what is the attitude of other people present in such a place towards the punishable act of a perpetrator. ${ }^{10}$ In order to determine what is a public place, it is also justified to make a reference to other legal provisions of an administrative nature, and this was expressed by the Supreme Court of the Republic of Poland in the case concerning alcohol consumption on the Vistula boulevard in Warsaw. Despite the fact that, at the time of committing the act referred to by the Supreme Court of the Republic of Poland, Article 43.1.1, 14.1 and $14.2 \mathrm{a}-6$ of the act on upbringing in sobriety and counteracting alcoholism, ${ }^{11}$ did not include the expression "public place" but only provided a list of places in which it is prohibited to consume alcohol, the Supreme Court of the Republic of Poland stated the following:

the legislator failed to specify the definition of "a street" in the Code of Petty Offences and in other legal acts of a similar type, and, therefore - as correctly noted by the courts examining that case — the source provisions should be applied. ${ }^{12}$

Thus, the judicial decisions of the administrative courts indicate that "A public place has such features as availability to the general public and non-private character of a site." 13 However, it is worth adding that the legislator noticed inaccuracy of the wording of Article 14.2a of the act on upbringing in sobriety and counteracting

${ }^{8}$ Ibidem.

9 J. Długosz, [in:] M. Królikowski, R. Zawłocki (eds.), op. cit., p. 913.

${ }^{10}$ W. Jankowski, [in:] T. Grzegorczyk (ed.), Kodeks wykroczeń. Komentarz [Code of Petty Offences. Comment], Warszawa 2013, comment to Article 49, thesis no. 2.

${ }^{11}$ Act of 26 October 1982 on upbringing in sobriety and counteracting alcoholism, Polish Journal of Laws of 1982, no. 35, item 230.

12 Decision of the Supreme Court of the Republic of Poland of 19 January 2017, I KZP 14/16, LEX no. 2188618.

13 Judgment of the Polish Supreme Administrative Court of 11 May 2011, II OSK 821/10, Legalis no. 389014. 
alcoholism and decided to amend $i^{14}$ by replacing the existing list with the phrase "a public place." In turn, pursuant to the provisions of the Construction Law, the Polish Supreme Administrative Court stated that "“a public place' within the meaning of Article 30.1.4 of the Construction Law is an open place, which is available to general public, i.e. a place which can be used by an unrestricted number of people, regardless of who is the owner of such a property."15

\section{The Internet as a place of committing a crime}

Once again, technological progress poses many challenges for lawyers when it comes to the development of new regulations and the correct adjustment of valid rules to new realities. Undoubtedly, the codifiers of the Code of Petty Offences of 1971 and the Criminal Code of 1997, did not take into consideration any possible problem of the Internet as a place of committing a crime, a tool of committing a crime, or the said public place. As has been indicated, according to the well-established case law and opinions of the doctrine, a public place must fulfil the criteria of unrestricted access for an unlimited number of persons.

\subsection{The Internet as the referent of a place}

The opinion stating that the current statutory regulation, particularly the Code of Petty Offences of 1974, does not fit into contemporary reality and technological progress, was used by the Supreme Court of the Republic of Poland to demonstrate that the Internet may be understood as a public place of committing an act. However, it has to be noted, without judging here the accuracy of the decision of the Supreme Court of the Republic of Poland, that the arguments presented in the justification of that judgment are relatively poor and based mainly on purposive arguments, because the Supreme Court of the Republic of Poland did not sufficiently consider the supremacy of the literal interpretation of provisions of a repressive nature. There is no doubt that the linguistic interpretation is of special and priority importance with regard to particular meaning of the penal norms and their guarantees. ${ }^{16}$ This was especially noted by J. Kulesza, who criticised the said judgment and pointed out that "the Internet is, after all, a computer network, 'an internet,' 'a network of networks' comprised of three levels: backbone network,

${ }^{14}$ Act of 10 January 2018 on amendments to the act on upbringing in sobriety and counteracting alcoholism and the act on security of mass events, Polish Journal of Laws of 2018, item. 310.

15 Judgment of the Polish Supreme Administrative Court in Warsaw of 12 April 2013, II OSK 2472/11, LEX no. 1337377.

${ }^{16}$ W. Wróbel, A. Zoll, Polskie prawo karne. Część ogólna [Polish Criminal Law: General Part], Kraków 2013, p. 117. 
servers and routers, and, last but not least, users' devices"17 and consequently, the author referred to the linguistic interpretation of "a public place" and took a standpoint according to which that concept should be understood only as actual physical places. The author came to this conclusion by pointing out the linguistic interpretation of the features of "a place" and then "a public place."18 However, such reasoning should be considered as incorrect. The directive concerning colloquial language assumes that the interpretation of legal language is consistent with colloquial and natural language. ${ }^{19}$ On the other hand, the interpretation of colloquial language does not need to correspond entirely to the dictionary (technical) interpretation, and, therefore, one of the reasons which the Supreme Court of the Republic of Poland referred to, but without providing a proper analysis of the phenomenon, is civilisation and technological development. Meanwhile, in connection with the functioning of the Internet, the following phrases became an evident component of colloquial language: "cloud/disc space," "place on a website," "see you online," etc. A strict interpretation of the phrase "place of committing an act," which implies a place in the material reality, must refer only to a place of committing an act interpreted as a place of a perpetrator's action pursuant to Article 6.2 of the Criminal Code, 4.2 of the Code of Petty Offences and Article 31.1 of the Code of Criminal Procedure. In this respect, it cannot be stated that a perpetrator performed an act in the Internet, because it is not a place of his activity, but under such an interpretation it appears as an object of activity. In order to point out a complete lack of understanding of the essence of the matter, we need to mention a statement of one of the courts in Wroclaw concerning the definition of a place of committing a prohibited act, in which the court indicated that the headquarters of the Internet is located in Warsaw. ${ }^{20}$ With regard to this, the argument of the linguistic interpretation concerning the phrase "a public place" seems, in fact, to be insufficient. The above may also be confirmed by entirely opposite standpoints in the doctrine concerning the recognition of the Internet as a public place, which had existed before the passing of the said judgment by the Supreme Court of the Republic of Poland. ${ }^{21}$ There is also a partially incorrect argument stating that it is not physically possible for a perpetrator to be present in two places at the same time (in

17 J. Kulesza, "Glosa do postanowienia Sądu Najwyższego z dnia 17 kwietnia 2018 r., sygn. IV KK 296/17" [Gloss to the decision of the Supreme Court of 17th April 2018, case ref. no. IV KK 296/17], Prokuratura i Prawo 2019, no. 3, p. 118.

18 Ibidem.

${ }^{19}$ L. Morawski, Zasady wyktadni prawa [Principles of Interpretation of Law], Toruń 2010, p. 98.

20 https://tech.wp.pl/druga-strona-monitora-wiemy-gdzie-jest-siedziba-internetu6034838254133889a (accessed: 21.11.2019).

${ }^{21}$ Standpoint in favour presented by, among others, T. Bojarski, [in:] Komentarz do art. $141 \mathrm{KW}$ [Comment to Article 141 of the Code of Petty Offences], ed. T. Bojarski, Warszawa 2019, para. 3; standpoint against by, among others, J. Kulesza, [in:] Komentarz do art. $141 \mathrm{KW}$ [Comment to Article 141 of the Code of Petty Offences], ed. P. Daniluk, Warszawa 2019, para. 7. 
their own flat and in the Internet as a public place), because there is no possibility of bilocation and multilocation of living organisms. ${ }^{22}$ That argument is only true where it refers to two or more real places. The simultaneous activity in real and virtual space is possible without the splitting of a perpetrator.

\subsection{The authors' standpoint}

According to the authors of this dissertation, the Internet, pursuant to the applicable rules, may be acknowledged as a public place and, despite the lack of deeper considerations of the Supreme Court of the Republic of Poland concerning the linguistic interpretation of the objective feature, the authors agree with the Court's opinion in this regard. The Internet, according to the established colloquial meaning commonly used by majority of people, is a certain place, an area, an immaterial or virtual space. The above-mentioned arguments support the statement that the concept of "a public place" used in the provisions of the criminal law does not exclude such an interpretation. In particular, the Internet cannot be interpreted only pursuant to a dictionary definition, which is of a computer-based and technical nature, and which is probably mainly used only by graduates of Computer Science. At this point, it is reasonable to repeat the dictionary definition of the Internet according to which:

The Internet [English name], in Computer Science, an international computer network connecting local networks using the Internet protocol suite (TCP/IP), with a uniform resource locator and hostname (assigned to computers connected to a network) and information transfer protocols. ${ }^{23}$

This explanation does not express the complexity of understanding, comprehension and perception of the above-mentioned concept by an average user, to whom the sanctioned norms are addressed. Upon the announcement of the judgment of the Supreme Court of the Republic of Poland, there were many stormy discussions as well as irrelevant comments and concerns in the press, on Internet forums and legal blogs, which amounted to the acknowledgment that, pursuant to the critical justification of the Supreme Court of the Republic of Poland, it is prohibited to consume alcoholic beverages in the Internet, i.e. it is punishable to publish photos showing someone holding a beer, films from events, as it constitutes a petty offence of consumption of alcohol in a public place not designated for it, specified under Article 14.2a of the act on upbringing in sobriety and counteracting alcoholism. ${ }^{24}$ At this point, it has to be explained that, indeed, the Internet is a public place, but at the

22 J. Kulesza, op. cit., p. 125.

23 https:/encyklopedia.pwn.pl/haslo/Internet;3915155.html (accessed: 21.11.2019).

${ }^{24}$ Act of 26 October 1982 on upbringing in sobriety and counteracting alcoholism, Polish Journal of Laws of 1982, no. 35, item 230, Article 14.2a: "It is prohibited to consume alcoholic beverages in public places, with the exception of places designated for on-premises alcohol consumption, at the points of sale." 
same time it is a virtual place and, hence, actions of a person, particularly physiological acts which may be performed only in the "real world," cannot be applied to the virtual world. Therefore, it cannot be admitted that a person who publishes on Facebook their photo from holiday showing an act of sipping a cocktail, has been really consuming an alcoholic beverage in a public place. Such a person only presents the consumption of alcohol and does it in a public place (the Internet), and the presentation of consumption in a public place is not, in principle, subject to punishment. It is also not possible to be in possession of a knife, a machete or other similarly dangerous object, with the intention of using it with the aim of committing a crime in the Internet understood as a public place. ${ }^{25}$ After all, a murder of a virtual character in an online game does not constitute a crime. When assuming, in accordance with the Supreme Court of the Republic of Poland, that the Internet may be regarded as a public place, it is necessary to consider what conditions need to be fulfilled. The Supreme Court of the Republic of Poland attempted to undertake such considerations when it indicated the following:

It should also be noted in the circumstances of the case under consideration that the website of the association [...] (www.(...).pl), which prompted the Court to issue the decision, is a publicly accessible website, not secured with a login or password. This website may be visited by every user of the Internet. With regard to the above, it has to be assumed that this website includes content which is located in a specific place (particular space) of the Internet and is, at the same time, available for an unlimited number of people. The situation would be different, if that website was secured with a login and password which would authorise only a particular person or a group of persons specified by the administrator of such a separate virtual space to enter the website, because in the case of regulation of access by a website owner, by means of a login and password, such a place is no longer public, as it remains available only for a restricted number of members.

Thus, the Supreme Court of the Republic of Poland, with regard to the qualification of the Internet space, differentiates between a public place and non-public place, depending on whether or not the access is secured with a login and password. According to the authors, the assumption above should be assessed critically, or at least regarded as insufficient and inappropriate to the realities of functioning. The above is also indicated by J. Kulesza in his paper:

The reservation made by the Court, according to which the Internet is not a public place when the access to particular content is restricted by a website owner, by means of a login and password, turns out to be only an apparent limitation of the scope of punishability which suddenly increases due to the Court's interpretation and which concerns the types involving the feature of acting in a public place, if we agree with the Court that the Internet is a public place. ${ }^{26}$

${ }^{25}$ Act of 26 October 1982 on upbringing in sobriety and counteracting alcoholism, Polish Journal of Laws of 1982, no. 35, item 230, Article 50(a)1: "Any person who is in possession of a knife, a machete or other similarly dangerous object in a public place and in circumstances indicating intent to use them to commit a crime, shall be subject to punishment of arrest, restriction of liberty or a fine not lower than 3,000 PLN."

26 J. Kulesza, op. cit., p. 121. 
As has been noted by the above-mentioned author of the gloss, further considerations regarding the categorisation of particular "spaces of the Internet" as public places or non-public places, should be based on this ostensibility of limitation. If, pursuant to the position grounded in the doctrine, which, incidentally, was also pointed out in the analysed judgment of the Supreme Court of the Republic of Poland, a public place is also a place "the entry to which is possible only upon the purchase of an appropriate entry pass, a ticket, or upon the reception of an invitation (theatre, concert, cinema)," then it should be considered what is the virtual equivalent of "an entry pass." The answer to this question is, in fact, like a thick line separating the areas of the Internet which should be acknowledged as a public place from the private enclaves which are not such places. Based on the example of creating an account on Facebook, it can be seen that this can be done by everyone who feels like doing it and the registration, even in the case of not very witty users, does not take more than just a few minutes. It is difficult to understand why the registration of an account, which is only a formal requirement and is not a real and burdensome restriction in the access to content, was not acknowledged by the Supreme Court of the Republic of Poland as an entry pass (which additionally is free of charge). It cannot be fairly stated that if obtaining content published on a particular website depends entirely on "an applicant" who needs to fill in a short form including the choice of login name and password, and provide their e-mail address, then such a website cannot be visited by any Internet user and, as a consequence, this constitutes a real limitation and control of persons with access (a similar opinion presented by J. Kulesza ${ }^{27}$ ). Following the above, in our opinion the decisive factor is whether a user interested in obtaining access is in possession of relevant instruments to enter a particular Internet space entirely independently, without obtaining an arbitrary, individual and specific approval of an administrator of content which is published there. It is significant who takes a decision about the access. ${ }^{28}$ The statement assuming that everything which can be found in the Internet is located in a public place is incorrect, however, there is one exception to it: "Although the Internet is a virtual space, it should be acknowledged as a public place in every case, apart from the situation when the content located there is accessible only to an author." 29 Such a distinction would result in acknowledging that even a profile of a person who has a few friends and an account with all privacy settings would be a public place, and this, with regard to the scope and an administrator's provision of access to their content to chosen

27 Ibidem, p. 122.

28 Similar standpoint — ibidem.

${ }^{29}$ M. Cieszyńska-Klimek, "Odpowiedzialność za umieszczenie na stronie internetowej nieprzyzwoitych treści. Glosa do postanowienia Sądu Najwyższego z dnia 17 kwietnia 2018 r., IV KK 296/17" [Liability for placement indecent content on an Internet page. Gloss to the decision of the Supreme Court of 17th April 2018], Gdańskie Studia Prawnicze - Przeglad Orzecznictwa 2018, no. 3 , p. 122. 
persons, is difficult to accept. To sum up the above, it is not sufficient to acknowledge a virtual space as a place other than public due to the necessity to complete registration, make a relevant payment for the access to "premium" content, fulfil the age criteria, etc. In the next section, we will focus on the presentation of the above-mentioned thesis on the basis of examples of functioning of selected, most popular social networking websites.

\section{The examples of activity in the Internet as a public place based on the analysis of functioning of the most popular social media}

Due to the fact that social media are popular and commonly used every day, the limited scope of analysis will focus on the possibilities of access settings concerning content published on Facebook and Instagram.

\subsection{Facebook}

\section{a. Posts}

When one publishes a text, a photo or a film on Facebook, they may choose the following options specifying the group of recipients: Public, Friends, Friends Except ..., Specific, Only Me. In the case when we accept the assumption discussed above, a post published in a public place will be a post published only under the option "public," because such a post will be visible to an unlimited group of people and every user, even a random one, will be able to view it. A post shared with friends indicates a closed, defined and limited group, whereas, if a person wants to become someone's friend on Facebook, their invitation must be accepted by a profile administrator. This means that a person who sent an invitation does not have access to content published on the "wall" without the voluntary decision of a profile owner. In the case of choosing the option "Friends Except," "Specific" or "Only Me," it is all the more impossible to talk about the content shared in a public place, because the group of people is even narrower. However, what should be taken into account, is the possibility that a person publishing a post at any time may change the group of recipients of a particular post or may delete it. It should be accepted that it is enough if a post marked as public is displayed on the profile at least for a moment, because what matters is the fact of sharing it in a public place. It would be possible to consider whether an act is socially harmful, depending on the period of time during which a published post was displayed in the virtual space. An interesting situation occurs when one tags their friend in a post. The information available at the Facebook Help Centre states that

When you tag someone, that content (example: photo, post) will be shared with the person tagged and their friends. This means that if you haven't already included their friends in the audience, their 
friends may not be able to see it. For example, if you tag Jane in a photo shared with your friends, the audience expands to Friends $(+)$ to include your friends and Jane's. ${ }^{30}$

In such a situation it still seems that we deal with a private area, because even though the circle of people widened, it is still specified and limited.

\section{b. Creating events}

On Facebook it is also possible to create events, in which it is possible to post photos, films and texts. When creating an event, it is possible to create a public and a private event. It is obvious that a public event, or rather posts included within it are published in a public place. On the other hand, the classification of a private event is interesting as it has additional privacy options. The explanation on Facebook concerning the choice of a private event is as follows: "Only invited guests will see your event. The host can allow guests to invite friends to the event." Therefore, what happens if the host adds co-hosts or allows guests to invite other persons? It seems that in the case of adding several co-hosts, there is still an effective control of access for a limited number of people, however, in the case when the guests are allowed to invite other guests, and particularly when we consider how easy it is to send invitations and how many people use the Internet, we may be tempted to state that we deal with an event created in the Internet, which is a public place, because the control of people and, as a result, the privacy of content, is apparent. An example which particularly supports the above statement is a private event created on Facebook, known as a party in Zakrzówek, which ended up in court. According to the information submitted by the host, initially the invitations to the event were sent only to friends who were allowed to invite other friends. However, the event got entirely out of the host's control and, in consequence, a mass event for over 20 thousand people was organised. ${ }^{31}$

\section{c. Creating groups}

Facebook offers provide the option of creating thematic groups, which also specifies particular privacy and access settings. It is possible to create a closed, secret or public group. Facebook Help Centre offers the most detailed explanation of this matter:

"When you create a group, you can choose 3 privacy settings: Public, Closed or Secret." The table below shows who can join these groups and which people can see them.

${ }^{30} \mathrm{https} / / / \mathrm{www}$. facebook.com/help/167941163265974?helpref=related (accessed: 21.11.2019).

${ }^{31} \mathrm{https}$ ://natemat.pl/81303,8-lat-wiezienia-za-organizacje-imprezy-na-krakowskim-zakrzowku-23-latka-ktora-zalozyla-wydarzenie-na-facebooku-uslyszala-zarzuty (accessed: 21.11.2019). 
Tab. 1. Facebook's privacy settings for groups

\begin{tabular}{|l|l|l|l|}
\hline & \multicolumn{1}{|c|}{ Public } & \multicolumn{1}{|c|}{ Closed } & \multicolumn{1}{|c|}{ Secret } \\
\hline $\begin{array}{l}\text { Who can see the group's } \\
\text { name? }\end{array}$ & Anyone & Anyone & $\begin{array}{l}\text { Current and former } \\
\text { members }\end{array}$ \\
\hline $\begin{array}{l}\text { Who can see the group de- } \\
\text { scription? }\end{array}$ & Anyone & Anyone & $\begin{array}{l}\text { Current and former } \\
\text { members }\end{array}$ \\
\hline $\begin{array}{l}\text { Who can see the list of } \\
\text { members in the group? }\end{array}$ & $\begin{array}{l}\text { People on } \\
\text { Facebook }\end{array}$ & Current members & Current members \\
\hline $\begin{array}{l}\text { Who can see admins and } \\
\text { moderators in the group? }\end{array}$ & $\begin{array}{l}\text { People on } \\
\text { Facebook }\end{array}$ & $\begin{array}{l}\text { People on } \\
\text { Facebook }\end{array}$ & Current members \\
\hline $\begin{array}{l}\text { Who can see which mem- } \\
\text { bers post in the group? }\end{array}$ & Anyone & Current members & Current members \\
\hline $\begin{array}{l}\text { Who can find the group in } \\
\text { Facebook search? }\end{array}$ & $\begin{array}{l}\text { People on } \\
\text { Facebook }\end{array}$ & $\begin{array}{l}\text { People on } \\
\text { Facebook }\end{array}$ & Current members \\
\hline Who can request to join? & $\begin{array}{l}\text { People on } \\
\text { Facebook }\end{array}$ & $\begin{array}{l}\text { People on } \\
\text { Facebook }\end{array}$ & Former members \\
\hline $\begin{array}{l}\text { Who can see stories about } \\
\text { the group on Facebook } \\
\text { (e.g. News Feed and } \\
\text { search? }\end{array}$ & $\begin{array}{l}\text { People on } \\
\text { Facebook }\end{array}$ & Current members & Current members \\
\hline
\end{tabular}

Source: https://www.facebook.com/help/220336891328465\#What-are-the-privacy-options-for-groups (accessed: 21.11.2019).

The analysis of this detailed explanation should assume that a public group constitutes a virtual space which is a public place. A secret group is a private online enclave available only for people chosen on the basis of the preferences of the group's administrator. When it comes to a closed a group, there is a question whether its name, description, administrators and moderators are visible to everyone and whether it can be searched in the search bar. It should be assumed that although the description of what is inside the group is available to everyone, it does not, in principle, constitute the disclosure of content addressed only to its members. However, according to the authors, the key matter, just like in the case of events, is the allocation of right to approve new group members by every member (which may be an apparent and uncontrolled restriction) or the possibility of turning on the option of approval only by the group administrators and moderators the said problem is not present in a secret group, because in such a group an interested person does not have the possibility to submit a request for access approval, and the whole procedure is based on an individual invitation of the administrator, without granting further rights to the group members. 


\subsection{Instagram}

Instagram is the second most popular application which is discussed in this paper. Instagram is generally a photo and video-sharing social networking service where people publish photos and videos and have the possibility to edit them and, among other things, to add text on photos. The considerations based on the possibilities and settings of Facebook and the resulting conclusions regarding an appropriate classification of an act in a public place or a place other than public place, shall be presented in analogous situations when using Instagram.

\section{a. Profiles}

Expanding an audience of published content is similar to doing it on Facebook. There are the so-called "Following" and "Followers" on Instagram. Depending on their profile privacy settings, to become a follower of a particular profile one only has to tap "Follow," and then all the most recent posts of all the followed users are displayed in their news feed section. If a profile is private, one needs to wait until a profile owner approves their follower request. Already at this point, in accordance with the adopted criterion, we can acknowledge that public profiles of Instagram users constitute a public place, because the access to them is unrestricted (Instagram does not even require one to have their own account in order to view the profiles of other users). On the other hand, profiles with privacy settings on the basis of which approval of a profile administrator is required to get a new follower are not public places.

\section{b. Stories}

There is the function of adding so-called "stories" on Facebook, Instagram and Snapchat which have different names in the above-mentioned social networking services, however, the way they work is very similar. The stories posted on Instagram are the most popular and, therefore, they will be discussed here. When you tap the option "Your Story" on Instagram, you will be redirected to the panel which will enable you to take a photo or record a video in order to post it, or to choose photos or videos from your device's gallery. We have a choice either to share the chosen content with all followers or with a close friends list, or we can send such a message only to a chosen person. If an Instagram user shares their stories, or one particular story, without narrowing the audience to a close friend list, then, depending on the general privacy settings, they will act in a public place or a place which cannot be classified as public due to the limitation of the audience of a story only to previously approved followers (who, for simplification purposes, should be treated as friends on Facebook). A published story is visible on Instagram for 24 hours from the moment of posting. However, the temporal nature of the content should not have any meaning for 
the classification of a public place. As an aside, it should also be mentioned that "snaps" on the Snapchat application, depending on our choice, are posted with a time limit, which can be even up to a few seconds, to control how long recipients can view them.

\section{c. Sharing content between social networking sites}

The cooperation between social networking sites results in the fact that when a user posts content on Instagram, Facebook, Twitter, etc., they have the possibility to publish the same post on a different site. At this point, it has to be indicated that if the same post is displayed on various social networking sites where a user has different privacy settings, then the qualification of a shared post as published in a public place should, in this case, be applied separately to each place, because in the case of publishing a post simultaneously on Facebook, Instagram and Twitter, such a user publishes it not in one but at least three places.

\section{Conclusion}

To sum up the above considerations regarding the interpretation of the expression "public place" used in the context of features of a prohibited act, either a crime or a petty offence, it has to be pointed out that this concept may be interpreted not only as places in the real world (a park, a street or a market square), but also, under certain conditions, as areas of virtual reality. Admittedly, with regard to the discussed area, it would, prima facie, seem that the grounds of linguistic interpretation and the principles of the specificity and certainty of criminal provisions shall indicate that the act of a perpetrator should take place in the real world, however, it must be taken into account that in the 21st century the Internet is part of the real world. Therefore, the sanctioned norms prescribing particular conduct must also be applied to the virtual world. On the other hand, the indications included in the said judgment of the Supreme Court of the Republic of Poland are based on a general argumentation referring to the purposive interpretation, and basically are reduced to the de lege ferenda postulate to provide such amendments to legal provisions, which would result in the equation of the features of "a public place" and a "public" action. If the legislator clearly distinguishes between these two concepts, then it cannot be assumed that they mean the same thing. Meanwhile, the above analysis of the meaning of this concept and the examples from social networking services indicate that it is not necessary to implement any legislative changes in this regard, because the features are sufficiently distinguishable. However, on the other hand, it has to be clearly pointed out that it is not possible to perceive the Internet as a public place in cases where the causative action of a particular prohibited act may be performed only in the real world. One of the examples is drinking 
alcohol in a public place, which constitutes a petty offence under Article 43(1) of the act on upbringing in sobriety and counteracting alcoholism. A negative phenome on referred to as "pathostream," which is frequent in recent times and which is based on live transmission on social networking sites of pathological behaviours that include drinking alcohol, cannot be perceived as consumption of alcohol in a public place. Content on YouTube which show the tasting and reviews of alcoholic beverages shall be judged similarly.

\section{References}

Bojarski T., [in:] Komentarz do art. $141 \mathrm{KW}$ [Comment to Article 141 of the Code of Petty Offences], ed. T. Bojarski, Warszawa 2019.

Cieszyńska-Klimek M., "Odpowiedzialność za umieszczenie na stronie internetowej nieprzyzwoitych treści. Glosa do postanowienia Sądu Najwyższego z dnia 17 kwietnia 2018 r., IV KK 296/17" [Liability for placement indecent contents on an Internet page. Gloss to the decision of the Supreme Court of 17 April 2018., IV KK 296/17], Gdańskie Studia Prawnicze - Przeglad Orzecznictwa 2018, no. 3.

Grzegorczyk T. (ed.), Kodeks wykroczeń. Komentarz [Code of Petty Offences. Comment], Warszawa 2013.

Królikowski M., Zawłocki R. (eds.), Kodeks karny. Część szczególna, vol. 1. Komentarz. Art. 117221 [Criminal Code. Detailed Part, vol. 1. Comment. Articles 117-221], Warszawa 2017.

Kulesza J., [in:] Komentarz do art. $141 \mathrm{KW}$ [Comment to Article 141 of the Code of Petty Offences], ed. P. Daniluk, Warszawa 2019.

Kulesza J., "Glosa do postanowienia Sądu Najwyższego z dnia 17 kwietnia 2018 r., sygn. IV KK 296/17" [Gloss to the decision of the Supreme Court of 17 April 2018, case ref. no. IV KK 296/17], Prokuratura i Prawo 2019, no. 3.

Morawski L., Zasady wyktadni prawa [Principles of Interpretation of Law], Torun 2010.

Wróbel W., Zoll A., Kodeks karny. Część szczególna, vol. 2. Część I. Komentarz do art. 117-211a [Criminal Code. Detailed Part, vol. 2. Part I. Comment to Articles 117-211a], Warszawa 2017. Wróbel W., Zoll A., Polskie prawo karne. Część ogólna [Polish Criminal Law: General Part], Kraków 2013.

\section{Internet sources}

https://encyklopedia.pwn.pl/haslo/Internet;3915155.html.

https://natemat.pl/81303,8-lat-wiezienia-za-organizacje-imprezy-na-krakowskim-zakrzow-

ku-23-latka-ktora-zalozyla-wydarzenie-na-facebooku-uslyszala-zarzuty.

https://www.facebook.com/help/167941163265974?helpref=related. 